\title{
GOVERNANCE STRUCTURES FOR OPEN INNOVATION: A Preliminary Framework
}

\author{
Joseph Feller \\ Patrick Finnegan \\ Jeremy Hayes \\ Philip O'Reilly \\ University College, Cork \\ Cork, Ireland
}

\begin{abstract}
This research-in-progress paper presents a preliminary framework of four open innovation governance structures. The study seeks to describe four distinct ways in which firms utilize hierarchical relationships, organizational intermediaries, and the market system to supply and acquire intellectual property and/or innovation capabilities from sources external to the firm. This paper reports on phase one of the study, which involved an analysis of six open innovation exemplars based on public data. This phase of the study reveals that governance structures for open innovation can be categorized based on whether they (1) are mediated or direct or (2) seek to acquire intellectual property or innovation capability. We analyze the differences in four governance structures along seven dimensions, and reveal the importance of knowledge dispersion and uncertainty to the use of open innovation hierarchies, brokerages, and markets. The paper concludes by examining the implications of the findings and outlining the next phase of the study.
\end{abstract}

Keywords Open innovation, governance structures, hierarchies, markets, brokerages

Please use the following format when citing this chapter:

Feller, J., Finnegan, P., Hayes, J., and O'Reilly, P., 2008, in IFIP International Federation for Information Processing, Volume 287, Open IT-Based Innovation: Moving Towards Cooperative IT Transfer and Knowledge Diffusion, eds. León, G., Bernardos, A., Casar, J., Kautz, K., and DeGross, J. (Boston: Springer), pp. 511-525. 


\section{INTRODUCTION}

Research has confirmed that firms that innovate their processes, products, and/or services outperform their competitors (Tidd 2000). However, the management of such innovation is both difficult and risky (Tidd et al. 2005) and many managers are dissatisfied with their firm's approach to managing this challenge (Arthur D. Little 2005). At its core, innovation is about knowledge and emerges as a result of combining different knowledge sets (Nonaka, et al. 2003; Tidd et al. 2005). However, such knowledge is frequently to be found outside the firm, and over the last few years increasing attention has been given to the concept of open innovation, namely,

The use of purposive inflows and outflows of knowledge to accelerate internal innovation, and expand the markets for external use of innovation, respectively. Open innovation is a paradigm that assumes that firms can and should use external ideas as well as internal ideas, and internal and external paths to market, as they look to advance their technology... This approach places external ideas and external paths to market on the same level of importance as that reserved for internal ideas and paths to market in the earlier era. (Chesbrough 2005, p. 1)

In the open innovation paradigm, firms supplement, or even supplant, internal research and development efforts by leveraging a variety of sources for knowledge inflows including suppliers, partners, customers, competitors, academic researchers, etc. Firms also supplement existing models and markets by exploiting intellectual property (IP) in a variety of ways such as licensing IP to those outside of the firm and spinning off ventures that can tackle new markets in ways the originating firm cannot (outflows) (Chesbrough 2003). To date, research on open innovation has focused primarily on the internal business model aspects of the concept (Chesbrough 2003, 2006; West et al. 2006). However, less attention has been devoted to interorganizational and business network aspects (Vanhaverbeke 2006; Vanhaverbeke and Cloodt 2006). Because firms seeking to implement open innovation practices are embedded within sectors, industries, and networks, future research on open innovation must consider the economic structures, institutions, and regulatory environments in which these firms operate (West et al. 2006).

This paper presents the initial findings from phase one of a study examining governance structures for open innovation. The concept of governance, adopted from the economics literature, refers to the contractual frameworks that govern interfirm relationships for supplying and acquiring resources, thus leading to mutual gains (Hayek 1945). The paper begins by drawing on extant research to examine the conditions that give rise to hierarchies, markets, and intermediaries as governance structures for interfirm relationships. We argue that firms may seek to acquire innovation resources (skills and solutions) outside the firm due to factors such as resource scarcity, cost, economies of scale, resource utilization, and relative advantage. We illustrate that while traditional interfirm licensing agreements are characterized by hierarchical arrangements, the dispersed nature of knowledge outside firm boundaries will lead to the use of other governance structures such as mediated and direct market structures. This is followed by an overview of the methodology used for the study. Our analysis reveals four governance structures for 
open innovation. We characterize these structures to reveal the importance of knowledge dispersion and uncertainty to the use of open innovation hierarchies, brokerages, and markets. Finally, we conclude by outlining the future stages of the study.

\section{THEORETICAL GROUNDING}

Researchers such as Coase (1937) envisaged that all resource production would take place within a firm unless the cost of doing so exceeded the cost of acquiring the resource externally. Building on the cost view, other researchers acknowledge the importance of factors such as economies of scale, increased resource utilization, and utilizing relative advantage such as productive capacity, managerial capacity, and technological know-how in determining what is produced within a firm and what is acquired externally (Clemons and Row 1992; Kumar and van Dissel 1996). In particular, resource dependency theory proposes that actors lacking in essential resources will seek to establish cooperative relationships with other organizations in order to obtain resources and reduce uncertainty (Pfeffer and Salancik 1978; Tilquist et al. 2002). Drawing upon Benson's (1975) work on political economy and social exchange mechanisms (see Emerson 1962, 1972), Pfeffer and Salancik (1978) identify three factors that determine the dependence of one organization on another:

- The importance of the resource (the extent to which an organization requires it for continued operation and survival).

- The extent of the discretion over the allocation and use of a resource possessed by the organization.

- The extent to which there are few alternatives, or concentration, of resource control.

Transactions with external parties to acquire resources entail uncertainty about their outcome due to bounded rationality and opportunism of agents. To overcome this uncertainty, and as a means of reducing transaction costs, agents implement a governance structure (Williamson 1991). A governance structure is "the explicit or implicit contractual framework within which a transaction is located" (Williamson 1981, p. 1544). Therefore, governance is viewed as a mechanism that instils order in an interorganizational relationship where potential conflict threatens to undo or upset opportunities to realize mutual gains (Williamson 1999).

Governance structures are generally regarded as being either hierarchical or market structures (Hess and Kemerer 1994; Schmid 199). A hierarchy is defined as a structure that spans two separate entities; it both represents a long-term relationship between organizations, and also governs that relationship by managerial decisions (Schmid 1993). Consequently, predefined standards and rules are used to coordinate activities between organizations (Robey and Sales 1994). In determining why organizations choose hierarchies, rather than the market mechanism, Coase (1937, p. 337) stated that

It may be desired to make a long-term contract for the supply of some article or service. This may be due to the fact that if one contract is made for a longer period, instead of several shorter ones, then certain costs of making contracts 
will be avoided. Or owing to the risk attitude of the people concerned they may prefer to make a longer rather than a short term contract.

Firms acquiring IP from outside of the firm is not a new concept. For many years, firms have sought to acquire externally developed IP, perceiving that it is more efficient and effective to purchase or license existing IP, rather than reinvent the IP internally. The traditional approach by which firms acquire external IP can be characterized as being primarily hierarchical in nature (Oxley 1999).

The second structure by which extra-organizational activities may be coordinated is a market; representing arm's-length and short-term relationships between participants (Malone et al. 1987). Traditionally, the price mechanism has been used to coordinate the activities of firms operating in a particular market (Hayek 1945). However, other factors (such as quantity, design, and delivery target schedule) may also be utilized to coordinate activities in the market (Hess and Kemerer 1994; Malone et al. 1987).

Revealing the importance of knowledge to the choice of governance structure, Hayek (1945) argued that knowledge does not exist in a concentrated or integrated form but as "dispersed bits of incomplete and frequently contradictory knowledge which all separate individuals possess" (p. 77). He argued that the main problem for individual firms is how to secure the best use of resources given the dispersed nature of knowledge. He believed that one of the key considerations in what he defines as the knowledge economy is the process by which individuals obtain such knowledge in order to make their decisions. In addition to markets and hierarchies, Hayek saw the emergence of intermediaries to aggregate disparate information and knowledge. Researchers (e.g., Clemons and Weber 1990; Lee and Clarke 1996) have adopted the concept of market intermediaries to distinguish between decentralized (direct search) and centralized (mediated) markets. The characteristics of decentralized and centralized market relationships together with hierarchies are summarized in Table 1.

A decentralized market refers to a market without an intermediary while a centralized market refers to a market with intermediaries. In a decentralized market, all participants are in contact with all possible trading partners and they each make their own decisions about which transactions to accept. Thus, there are high search costs due to the fact

Table 1. Characteristics of Hierarchical, Decentralized, and Centralized Market Relationships

\begin{tabular}{|c|c|}
\hline Type of Relationship & Characteristics \\
\hline Hierarchy & $\begin{array}{l}\text { - Structure that spans two separate firms } \\
\text { - Long-term relationship between firms } \\
\text { - Relationship governed by managerial decisions }\end{array}$ \\
\hline Decentralized Market & $\begin{array}{l}\text { - Parties search each other out directly } \\
\text { - No intermediary involved } \\
\text { - High search costs } \\
\text { - Typically arm's length and short term in nature }\end{array}$ \\
\hline Centralized Market & $\begin{array}{l}\text { - Intermediaries assist in search process } \\
\text { - Intermediaries possess market knowledge } \\
\text { - Improved search capabilities possibly offset by higher uncertainty } \\
\text { - Typically arm's length and short term in nature }\end{array}$ \\
\hline
\end{tabular}


that each party must directly discover each possible partner (Palmer and Lindemann 2003). In a centralized market, by contrast, participants do not need to contact all potential trading counterparts because an intermediary is already in contact with them (Lee and Clarke 1996). Such markets are commonly referred to as broker markets (or brokerages). In brokerages, the role of the broker is to provide additional processes to the market and lower search costs. This is commonly achieved through the additional information available to the broker about the market. In such markets, participants utilize the brokers to conduct the research for them, and to provide specialized knowledge of assets traded in a particular market (Bodie et al. 2004). However, higher uncertainty, time delays, suboptimal prices, participation fees, etc. may offset the value of improved search capabilities and external market knowledge in a broker market (Palmer and Lindemann 2003).

\section{RESEARCH METHOD}

The objective of our study is to explore governance structures for open innovation. Our research method follows in the tradition of Eisenhardt (1989) and Madill et al. (2000); it is designed to reveal preexisting, relatively stable, and objectively extant phenomena and the relationships among them in a manner that is not limited to examining only pre-identified constructs.

In the current phase of the study, we began with extant theories of governance to frame our exploration of the use of hierarchical, decentralized, and centralized market relationships for open innovation. This is in line with Lee and Baskerville (2003) who, in addressing the issue of generalization, document the process of generalizing from theory to empirical description (research seeks to apply theoretical findings confirmed in one setting to another setting). This phase of the study was concerned with achieving an increased understanding of the open innovation phenomenon. In particular, we sought to develop a rich description (based on secondary data analysis and publicly available primary data) of six exemplars of open innovation: InnoCentive, Yet2, YourEncore, Threadless, NineSigma, and Proctor and Gamble's Connect + Develop Initiative (see Table 2). Several researchers (e.g., Huston and Sakkab 2006; Motzek 2007) have identified these sites as being among the leading systems in terms of open innovation.

Data for the study was gathered over a three-month period. Data was gathered from (1) published content from the companies, (2) analysis of the web-based systems utilized by the companies (where applicable), and (3) academic and industry publications related to the companies.

Content analysis was undertaken using grounded theory coding techniques as proposed by Strauss and Corbin (1990) and exemplified by the research of Orlikowski, (1993) and Urquhart (1997). This approach necessitates the researchers to be immersed in the data (Glaser and Strauss 1967) and to draw on existing theoretical knowledge without imposing a theory (Corbin and Strauss 1990; Urquhart 1997). It thus encourages the researcher to be flexible and creative (Sarker et al. 2000) while imposing systematic coding procedures (Strauss and Corbin 1990).

The first step (open coding) involved the data being examined line by line to ascertain the main ideas. These were then grouped by meaningful headings to reveal categories and subcategories/properties. The next step (axial coding) was the process of 
determining hypotheses about the relationships between a category and its subcategories (e.g., conditions, context, action/interaction strategies, and consequences). The focus then turned to the data to assess the validity of these hypothesized relationships. Relational and variational sampling (see Strauss and Corbin 1990) was used to select data for this analysis. This process continued in an iterative manner and resulted in the modification of categories and relationships. Finally, selective coding was undertaken to identify the relationships between categories (constructs) using hypothesized conditions, context, strategies, and consequences. Discriminate sampling (Strauss and Corbin 1990) was used to select data to examine strong and weak connections between categories.

\section{Table 2. Open Innovation Exemplars Examined in this Study}

\begin{tabular}{|c|c|}
\hline Company & Overview \\
\hline InnoCentive & $\begin{array}{l}\text { Established in 2001, InnoCentive (www.innocentive.com) provides a web site } \\
\text { where firms (called "seekers") can post problems to be solved (called "chal- } \\
\text { lenges") in over } 40 \text { industry disciplines in the areas of physical, life and com- } \\
\text { puter sciences, chemistry, engineering and design, and business and entre- } \\
\text { preneurship. A community of over } 125,000 \text { experts (called "solvers") review } \\
\text { the posted challenges, and possibly propose solutions. Seekers evaluate the } \\
\text { solutions, and possibly purchase one or more that meet their needs. }\end{array}$ \\
\hline NineSigma & $\begin{array}{l}\text { Established in 2000, NineSigma (www.ninesigma.com) work on behalf of } \\
\text { clients to source ideas, technologies, products and services from innovators } \\
\text { outside the client's organization. NineSigma possess a multinational, multi- } \\
\text { disciplinary proprietary network of scientists, university researchers, and } \\
\text { technology incubators (referred to as "solution providers") that have signed up } \\
\text { to NineSigma through their website. NineSigma works closely with clients } \\
\text { throughout the due diligence, request for proposal, response management, and } \\
\text { solution evaluation processes. }\end{array}$ \\
\hline Yet 2 & $\begin{array}{l}\text { Established in 1999, Yet2 (www.yet2.com) provides a web site through which } \\
\text { companies can list existing technology solutions they wish to sell/license or list } \\
\text { technology needs they wish to fulfill. Yet } 2 \text { assist buyers in locating appropriate } \\
\text { technology solutions for their problems, and facilitates sellers in generating } \\
\text { revenue through the sale/licensing of IP. Yet } 2 \text { has over } 100,000 \text { registered } \\
\text { users and thousands of listings of technologies and technology needs. }\end{array}$ \\
\hline YourEncore & $\begin{array}{l}\text { Established in 2003, YourEncore (www.yourencore.com) maintains a network } \\
\text { of retired/veteran scientists, engineers, and other experts, and offer companies } \\
\text { (in the United States only) the ability to utilize these experts to solve problems } \\
\text { on a short-term assignment basis, either remotely or on-site. }\end{array}$ \\
\hline Threadless & $\begin{array}{l}\text { Established in 2000, Threadless (www.threadless.com) is an online t-shirt } \\
\text { retailer that derives all of its t-shirt designs from members of its online } \\
\text { community through a weekly competition. Members of the community create } \\
\text { all designs, and the community votes on contributed designs to determine what } \\
\text { shirts are actually manufactured and sold. In } 2006 \text {, Threadless sold } \$ 16 \text { million } \\
\text { worth of t-shirts (Weingarten 2007). }\end{array}$ \\
\hline $\begin{array}{l}\text { Proctor and } \\
\text { Gamble }\end{array}$ & $\begin{array}{l}\text { Established in } 1999 \text {, Proctor and Gamble's Connect }+ \text { Develop initiative (www. } \\
\text { pgconnectdevelop.com) has a dual purpose. First, it provides a mechanism for } \\
\text { solution providers to either address specific P\&G needs, or to propose } \\
\text { innovations that may be of interest to the firm. Second, it provides a mech- } \\
\text { anism for P\&G to make potential buyers aware of existing IP that is available } \\
\text { for licensing. }\end{array}$ \\
\hline
\end{tabular}


In the next phase of the study, we will continue our investigation of the organizations examined in the current phase using interviews and a survey. That phase is outlined at the end of this paper.

\section{FINDINGS}

In this section, we describe the findings from the first phase of our study, which has revealed four potential open innovation governance structures, differentiated along two axes (see Figure 1):

- Configuration: whether the structure is direct (e.g., a hierarchy or decentralized market) or mediated (e.g., a brokerage)

- Focus: whether the structure enables the sale/purchase of existing intellectual property or of innovation capability (access to experts capable of creating new IP)

\subsection{Solution Hierarchy}

The Connect + Develop initiative is part of Proctor and Gamble's commitment to having 50 percent of the company's ideas and innovations come from external sources (Chesbrough 2003). The initiative facilitates P\&G's effort to supplement the innovation capabilities of approximately 8,600 internal researchers with the capabilities of an esti-

\section{Focus}

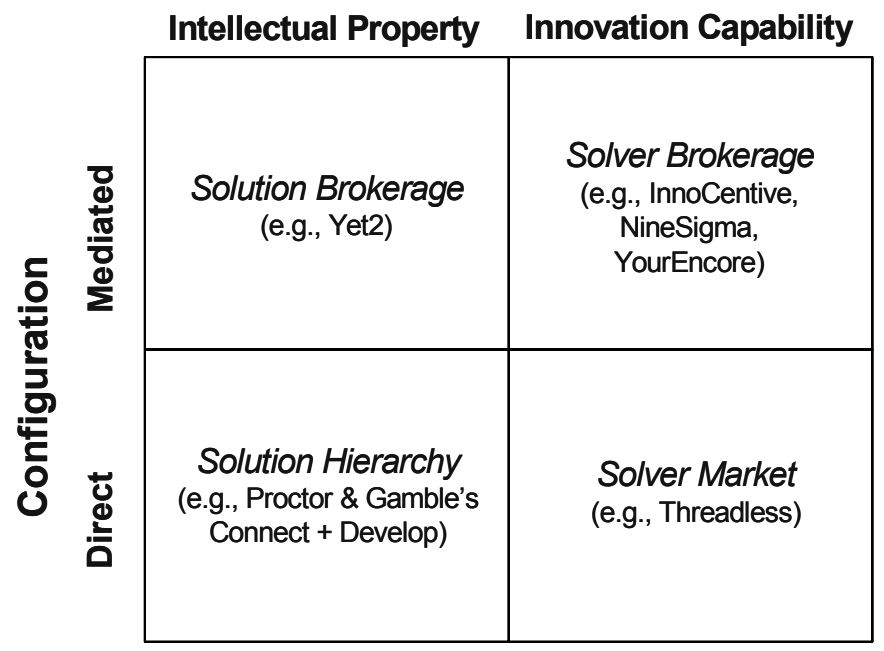

Figure 1. Open Innovation Governance Structures 
mated 1.5 million external innovators with relevant skills (Chesbrough 2003). In order to access and manage the large number of potential external researchers, Connect + Develop utilizes a dedicated website to facilitate parties proposing new innovations. Additionally, the firm monitors a wide variety of innovation sources including professional and academic events, publications, and research labs in an ongoing commitment to identifying external innovation capabilities. Finally, P\&G utilizes the Connect + Develop website as a mechanism for marketing their own IP which is available for sale/licensing.

We characterize the Connect + Develop initiative as a solution hierarchy (as noted in the literature review section, the traditional approach to sourcing external IP can also be characterized in this way). P\&G utilizes the Connect + Develop website to discover and directly acquire externally developed IP to create new products or significantly improve existing products. For example, $\mathrm{P} \& \mathrm{G}$ 's blockbuster product, Olay Regenerist, was initially developed by a small cosmetics company in France. After P\&G's skin-care researchers became aware of the product, they purchased the IP for the product. The French company now continues to collaborate with $\mathrm{P} \& \mathrm{G}$ to develop new products for P\&G. The Olay Regenerist example illustrates some of the key characteristics of the solution hierarchy structure.

First, the primary activity is on the direct acquisition of existing IP. Second, the solution was acquired from a well-known provider, the identification of which was facilitated by the use of IT (the web site) to coordinate discovery activities. Third, the subsequent engagement with the seller was direct and involved strong ties between the parties and the establishment of a long-term relationship with a large amount of interaction taking place between personnel from both firms. Fourth, although the transaction has led to ongoing collaboration between the two firms, the actual acquisition of the existing IP by $P \& G$ is characterized by low levels of interdependency between the buyer and seller. Fifth, participation in this model involves high costs for P\&G (or any buyer) associated with defining the problem, sourcing the solution, evaluating both potential trading partners and potential solutions, managing legal and logistic details, etc. In the Olay Regenerist example, these costs were primarily associated with search, evaluation and negotiation for the IP. Finally, because there are clearly defined rules and procedures (legal agreements) to define the relationship between parties, there are lows levels of uncertainty for both the licensor and licensee.

It is also worth noting that for $P \& G$, the solution hierarchy is used not only to enable the purchase of IP but also the sale. For example, $\mathrm{P} \& \mathrm{G}$ 's prior business in producing a line of fruit juice products led to the discovery of Calsura, a more absorbable form of calcium that can be added to food or drink to increase its nutritional content. Calsura has been licensed to several companies through the Connect + Develop initiative.

\subsection{Solution Brokerage}

Yet2 is an example of what we have labeled a solution brokerage, in which an intermediary company aggregates both products available for sale (IP available for licensing) and demand (a large and diverse population of potential buyers). Yet2 operates an electronic brokerage at Yet2.com, and also provides related professional services to both 
sellers (IP portfolio assessment and licensing services) and buyers (need specification and discovery services).

In doing so, the company seeks to

- $\quad$ enable sellers to realize a higher return on their IP investments

- $\quad$ enable buyers to acquire IP and access technology solutions rapidly and economically

From the seller's point of view, Yet2 provides the ability to reach a much wider and more diverse market than they could through direct sales. John Donofrio, Chief Patent Counsel at Honeywell, stated that "listing our technologies on Yet2.com enables our technology to benefit applications in industries where we would not normally participate, which provides us with new revenue growth opportunities that lead to added shareowner value" (Malik 2000).

From the buyer's perspective, the company reduces search costs through economies of scale and the prefiltering of false positives (all IP listed at Yet2.com is definitely available for purchase). Shunichi Samejima, of the Asahi Glass Company, notes that Yet2 provides their firm with "access to previously undisclosed technologies from companies in the forefront of global technology development." Additionally, Yet2 provides services to help innovation seekers clearly define their technology needs and manage the acquisition process.

In this governance structure, the broker works with solution providers to classify existing assets, devise opportunities for licensing, and provide access to buyers. For solution seekers, the broker applies its market knowledge to refine requirements specifications and locate prevalidated solutions. In doing so, the solution brokerage can mitigate the limitations of the solution hierarchy by lowering search costs and reducing uncertainty vis-à-vis problem definition and solution availability. In this structure, the intermediary owns the customer relationship, and all parties are governed by the rules and regulations set by the intermediary. Thus, ties between seekers and solvers are weak and low levels of interdependence exist between them.

\subsection{Solver Market}

Threadless is an example of the solver market structure, in which an organization goes directly to the market seeking to leverage the innovation capabilities of market participants in order to create new innovations to address organizational needs.

Threadless is an online t-shirt manufacturer/retailer that has shifted all new product development activity to the market. Members of its online community submit all of its t-shirt designs, and this same community votes on a weekly basis to determine what designs are actually manufactured. Thus the market is both the source of innovation capability and the mechanism for evaluating potential innovations. On average, over 700 designs will compete to be selected in any given week. The firm provides financial incentives to innovators (each creator of a selected design receives $\$ 2,000$ in cash as well as either an additional $\$ 200$ in cash or \$500 in store credit).

${ }^{1}$ Retrieved from http://www.yet2.com/app/about/about/quotes. 
In a solver market, the solution or innovation being sought does not already exist; it is created as an output of market participation. While the buyer may be confident that the innovation capabilities sought are present in the market, a high level of uncertainty remains regarding whether or not a solution to a specific problem can be found. Thus, while firms could seek to acquire innovation capability to address either specific or general problems, the structure would appear to work particularly well in scenarios where organizations are seeking capabilities to address a loosely defined problem space. For example, Threadless defines two broad categories for submissions-designs and slogans - rather than soliciting specific t-shirt designs.

In this governance structure, it is up to the seeker organization to deal with all financial and legal issues in relation to acquiring the desired capabilities, thus transaction costs remain high. Ties and interdependencies between seekers and solvers in such a structure may be either very weak or very strong depending on the mechanics of how the capability is eventually leveraged by the firm. For example, on Threadless, some innovators submit a single design that may or may not go into production. However, it also appears that some t-shirt designers have had multiple designs produced by Threadless and play a key ongoing role in the Threadless community.

\subsection{Solver Brokerage}

InnoCentive, NineSigma, and YourEncore are examples of our final governance structure, the solver brokerage. In this structure, an intermediary company aggregates both demand for capabilities (firms seeking innovators capable of meeting specific challenges) and supply (a large and diverse population of innovators). These companies all implement the structure in slightly different ways. InnoCentive emphasizes the demand side (potential innovators search catalogues of problems) while NineSigma and YourEncore emphasize the supply side (matchmaking firms with needs with potential solvers). In all instances, the broker creates additional value by helping firms define problems and evaluate potential solvers and their proposed solutions.

In this structure, the broker has the knowledge of the most likely solvers for a specific problem, thus lowering uncertainty for the seeker. However, it remains uncertain whether a solution can be developed for a specific problem; this is illustrated by the fact that not all problems published on InnoCentive, NineSigma, and YourEncore are actually solved.

As noted, the broker also acts to assist the seeker in defining the problem. For example, the exemplars examined all provide expertise to organizations to facilitate problem definition, bounding, and communication. The ways in which solvers are matched to problems varies from site to site. For example, YourEncore recommends specific problem solvers for specific tasks while InnoCentive allows solvers to self-select and then compete on the quality of their innovations; with either mechanism, there is a reduction of uncertainty for the seekers.

As with the solution brokerage, in this structure, the broker owns the customer relationship, and all parties are governed by the rules and regulations set by the broker. Thus, ties between seekers and solvers are weak. However, since the focus of this structure is on capabilities rather than products, interdependence between parties is high (as they must work together to achieve the actual solution). Costs for solution seekers and solvers are mitigated by the economies of scale of the intermediary. 


\section{CONCLUSIONS AND FUTURE RESEARCH}

The first phase of our study, as detailed in this research-in-progress paper, has delineated four governance structures for open innovation and illustrated differences between these structures in relation to seven characteristics (Table 3). Our analysis has illustrated the importance of knowledge/uncertainty in relation to open innovation. Of particular note is the uncertainty caused by the information asymmetry evident in the various exemplars of open innovation studied. This uncertainty manifests itself in relation to

- the existence and availability of potential solutions and solvers

- the suitability of potential innovation partners (solution providers and solvers)

- the acquisition process for external innovations (including problem specification, solution evaluation, transfer, etc)

As predicted by extant research, such uncertainty leads to high transactions costs (Williamson 1981, 1991) and the use of intermediaries (Hayek 1945). It is evident that intermediaries (solver/solution brokerages) allay uncertainty by (1) integrating the knowledge of seekers and solvers and (2) providing value-added services. In addition, the economies of scale created by brokers reduce transaction costs.

Building on transaction cost economics, organization theory, and political economy, the information processing perspective examines how uncertainty in interorganizational relations may be reduced using structures, processes, and technology (Bensaou and Venkatraman 1995). Moving forward, we seek to expand our treatment of the four governance structures discussed above by examining the interorganizational relationships within each of the governance structures, and how the structures and related processes and technology can be used to manage the knowledge dispersion and uncertainty evident in open innovation processes.

The next phase of the study thus involves an empirical investigation of the exemplars examined in phase one, together with other firms involved in open innovation. Data is being gathered using both (1) interviews and (2) a survey of seekers and solvers. This will enable us to

- more richly characterize the seeker-solver relationships prevalent within each governance structure

- examine how information processing capabilities (structure, process, and technology) may allay the environmental, partner and task uncertainty arising within each of these configurations

\section{Acknowledgments}

This work has been supported by the Irish Research Council for the Humanities and Social Sciences (IRCHSS) through the O3C Business Models Project. 
Table 3. Characteristics of Open Innovation Governance Structures

\begin{tabular}{|c|c|c|c|c|}
\hline Characteristic & $\begin{array}{c}\text { Solution } \\
\text { Hierarchy }\end{array}$ & $\begin{array}{c}\text { Solution } \\
\text { Brokerage }\end{array}$ & $\begin{array}{c}\text { Solver } \\
\text { Brokerage }\end{array}$ & Solver Market \\
\hline $\begin{array}{l}\text { Knowledge of solution/ } \\
\text { solver availability: } \\
\text { Which party knows } \\
\text { where a solution (or the } \\
\text { expertise to develop a } \\
\text { solution) can be found? }\end{array}$ & $\begin{array}{l}\text { The seeker has } \\
\text { knowledge of (or a } \\
\text { mechanism for } \\
\text { discovering) the } \\
\text { availability of } \\
\text { potential solutions } \\
\text { within a narrow } \\
\text { range of firm } \\
\text { alliances. }\end{array}$ & $\begin{array}{l}\text { Intermediary has } \\
\text { knowledge of the } \\
\text { availability of } \\
\text { potential solu- } \\
\text { tions. }\end{array}$ & $\begin{array}{l}\text { Intermediary } \\
\text { has knowledge } \\
\text { of the avail- } \\
\text { ability of poten- } \\
\text { tial solvers. }\end{array}$ & $\begin{array}{l}\text { The seeker has } \\
\text { knowledge of } \\
\text { the availability } \\
\text { of potential } \\
\text { solvers within a } \\
\text { broad setting. }\end{array}$ \\
\hline $\begin{array}{l}\text { Problem specification: } \\
\text { Who specifies the prob- } \\
\text { lem together with the } \\
\text { process of bounding and } \\
\text { communicating the } \\
\text { problem? }\end{array}$ & $\begin{array}{l}\text { Seeker specifies the } \\
\text { problem. }\end{array}$ & $\begin{array}{l}\text { Intermediary } \\
\text { helps solution } \\
\text { seekers specify } \\
\text { the problem. }\end{array}$ & $\begin{array}{l}\text { Intermediary } \\
\text { helps solution } \\
\text { seekers specify } \\
\text { the problem. }\end{array}$ & $\begin{array}{l}\text { Seeker specifies } \\
\text { the problem in } \\
\text { broad terms. }\end{array}$ \\
\hline $\begin{array}{l}\text { Knowledge of } \\
\text { acquiring innovation: } \\
\text { Who has expertise in } \\
\text { solution evaluation, } \\
\text { financial and legal } \\
\text { issues for the transfer of } \\
\text { IP, etc.? }\end{array}$ & $\begin{array}{l}\text { Seeker and solution } \\
\text { provider. }\end{array}$ & $\begin{array}{l}\text { Intermediary } \\
\text { provides the } \\
\text { value-added } \\
\text { services for both } \\
\text { parties. }\end{array}$ & $\begin{array}{l}\text { Intermediary } \\
\text { provides the } \\
\text { value-added } \\
\text { services for } \\
\text { both parties. }\end{array}$ & $\begin{array}{l}\text { For financial } \\
\text { and legal issues, } \\
\text { the seeker. } \\
\text { However, the } \\
\text { community of } \\
\text { solution pro- } \\
\text { viders can } \\
\text { potentially be } \\
\text { used for } \\
\text { evaluation and } \\
\text { related issues. }\end{array}$ \\
\hline $\begin{array}{l}\text { Seeker Uncertainty: } \\
\text { What is the degree of } \\
\text { uncertainty for seekers } \\
\text { in relation to potential } \\
\text { partners (solver/solution } \\
\text { provider) and product } \\
\text { availability? }\end{array}$ & $\begin{array}{l}\text { Low - solution and } \\
\text { provider known in } \\
\text { advance. }\end{array}$ & $\begin{array}{l}\text { Low - solution } \\
\text { can be evaluated } \\
\text { before investment } \\
\text { is made. } \\
\text { Intermediary vets } \\
\text { solution provider. }\end{array}$ & $\begin{array}{l}\text { Medium - no } \\
\text { guarantee of } \\
\text { solution. } \\
\text { Intermediary } \\
\text { vets solver. }\end{array}$ & $\begin{array}{l}\text { High }- \text { no } \\
\text { guarantee of } \\
\text { solution. No } \\
\text { advance vetting } \\
\text { of solver. }\end{array}$ \\
\hline $\begin{array}{l}\text { Seeker-solver ties: } \\
\text { What is the strength of } \\
\text { the relationship between } \\
\text { seekers and solvers? }\end{array}$ & $\begin{array}{l}\text { Strong - usually a } \\
\text { medium to long- } \\
\text { term relationship. }\end{array}$ & $\begin{array}{l}\text { Weak - usually a } \\
\text { short-term } \\
\text { relationship. }\end{array}$ & $\begin{array}{l}\text { Weak - usually } \\
\text { a short-term } \\
\text { relationship. }\end{array}$ & $\begin{array}{l}\text { Varies from } \\
\text { solver to solver. }\end{array}$ \\
\hline $\begin{array}{l}\text { Interdependency } \\
\text { between seeker and } \\
\text { solver: How dependent } \\
\text { is one party on the } \\
\text { other? }\end{array}$ & $\begin{array}{l}\text { Low - seeker } \\
\text { licenses the existing } \\
\text { solution. }\end{array}$ & $\begin{array}{l}\text { Low - seeker } \\
\text { licenses the } \\
\text { existing solution. }\end{array}$ & $\begin{array}{l}\text { High }- \text { seeker } \\
\text { and solver work } \\
\text { together to } \\
\text { develop the } \\
\text { solution. } \\
\end{array}$ & $\begin{array}{l}\text { High }- \text { seeker } \\
\text { and solver work } \\
\text { together to } \\
\text { develop the } \\
\text { solution. } \\
\end{array}$ \\
\hline $\begin{array}{l}\text { Transaction Cost: Who } \\
\text { is responsible for the } \\
\text { cost of finding a } \\
\text { solution/solver? }\end{array}$ & $\begin{array}{l}\text { Seekers must } \\
\text { absorb all costs of } \\
\text { locating, evalu- } \\
\text { ating, and acquiring } \\
\text { all solutions. }\end{array}$ & $\begin{array}{l}\text { Costs for seekers } \\
\text { and providers are } \\
\text { mitigated by the } \\
\text { economies of } \\
\text { scale of the } \\
\text { intermediary. }\end{array}$ & $\begin{array}{l}\text { Costs for } \\
\text { seekers and } \\
\text { providers are } \\
\text { mitigated by the } \\
\text { economies of } \\
\text { scale of the } \\
\text { intermediary. }\end{array}$ & $\begin{array}{l}\text { Seekers must } \\
\text { absorb all costs } \\
\text { of locating, } \\
\text { evaluating and } \\
\text { acquiring all } \\
\text { solutions. }\end{array}$ \\
\hline
\end{tabular}




\section{References}

Arthur D. Little. 2005. Global Innovation Excellence Study 2005, April (http://www.vno-ncw.nl/ web/servlet/nl.gx.vno.client.http.StreamDbContent?code=1244).

Bensaou, M., and Venkatraman, N. 1995. "Configurations of Interorganizational Relationships: A Comparison Between U.S. and Japanese Automakers," Management Science (41:9), pp. 1471-1492.

Benson, J. K. 1975. "The Interorganizational Network as a Political Economy,” Administrative Science Quarterly (20), pp. 229-249.

Bodie, Z., Kane, A., and Marcus, A. 2004. Essentials of Investment (5 ${ }^{\text {th }}$ ed.), New York: McGraw-Hill.

Charmaz, K. 2000. "Grounded Theory: Objectivist and Constructivist Methods," in Handbook of Qualitative Research, N. K. Denzin and Y. S. Lincoln (eds.), Thousand Oaks, CA: Sage Publications.

Chesbrough, H. 2003. Open Innovation: The New Imperative for Creating and Profiting from Technology, Boston: Harvard Business School Press.

Chesbrough, H. 2005. "Open Innovation: A New Paradigm for Understanding Industrial Innovation," in Open Innovation: Researching a New Paradigm, H. Chesbrough, W. Vanhaverbeke, and J. West (eds.),Oxford, UK: Oxford University Press, pp. 1-14.

Chesbrough, H. 2006. Open Business Models: How to Thrive in the New Innovation Landscape, Boston: Harvard Business School Press.

Clemons, E. K., and Row, M. C. 1992. "Information Technology and Industrial Cooperation: The Role of Changing Transaction Costs," Journal of Management Information Systems (9:2), pp. 9-28.

Clemons, E. K., and Weber, B. W. 1990. "London's Big Bang: A Case Study of Information Technology, Competitive Impact and Organizational Change," Journal of Management Information Systems (6:4), pp. 41-60.

Coase, R. 1937. "The Nature of the Firm," Economica (4:16), pp. 386-405.

Corbin, J., and Strauss, A. 1990. "Grounded Theory Research: Procedures, Canons, and Evaluative Criteria," Qualitative Sociology (13:1), pp. 3-21.

Eisendardt, K. M. 1989. "Building Theories from Case Study Research," Academy of Management Review (14:4), pp. 532-550.

Emerson, R. 1962. "Power-Dependence Relations," American Sociological Review (27), pp. $31-41$.

Emerson, R 1972. "Exchange Theory, Part II: Exchange Relations and Networks," in Sociological Theories in Progress, J. Berger, M. Zelditch Jr., and B. Anderson (eds.), Boston: Houghton Mifflin, pp. 58-87.

Glaser, B., and Strauss, A. 1967. The Discovery of Grounded Theory: Strategies for Qualitative Research, Chicago: Aldine Publishing Company.

Hayek, F. A. 1945. "The Use of Knowledge in Society," American Economic Review (35), pp. 519-530.

Hess, C. M., and Kemerer, C. F. 1994. “Computerized Loan Origination Systems: An Industry Case Study of the Electronic Market Hypothesis," MIS Quarterly (18:3), pp. 251-275.

Huston, L., and Sakkab, N. 2006. "Connect and Develop-Inside Procter \& Gamble's New Model for Innovation," Harvard Business Review, March, pp. 63-64.

Kumar, K., and van Dissel, H. G. 1996. "Sustainable Collaboration: Managing Conflict and Cooperation in Interorganizational Systems," MIS Quarterly (20:3), pp. 279-300.

Lee, A. S., and Baskerville, R. L. 2003. "Generalizing Generalizability in Information Systems Research," Information Systems Research (14:3), pp. 221-243.

Lee, H. G., and Clark, T. H. 1996. "Impacts of Electronic Marketplace on Transaction Cost and Market Structure, International Journal of Electronic Commerce (1:1), pp. 127-149. 
Madill, A., Jordan, A., and Shirley, C. 2000. “Objectivity and Reliability in Qualitative Analysis: Realist, Contextualist and Radical Constructionist Epistemologies," British Journal of Psychology (91:1), pp. 1-20.

Malone, T., Yates, J., and Benjamin, R. 1987. "Electronic Markets and Electronic Hierarchies," Communications of the ACM (30:6), pp. 484-497.

Malik, O. 2000. “Technology's Clearinghouse: Yet2.com," Forbes.com, February 7 (http://www.forbes.com/2000/02/07/mu3.html).

Motzek, R 2007. Motivation in Open Innovation, Saarbrücken, Germany: VDM Verlag Dr. Mueller e.K.

Nonaka, I., Keigo, S., and Ahmed, M. 2003. "Continuous Innovation: The Power of Tacit Knowledge," in International Handbook of Innovation, K. Shavinina (ed.), New York: Elsevier.

Orlikowski, W. J. 1993. "CASE Tools as Organizational Change: Investigating Incremental and Radical Changes in Systems Development," MIS Quarterly (17:3), pp. 309-340.

Oxley, J. E. 1999. "Institutional Environment and the Mechanisms of Governance: The Impact of Intellectual Property Protection on the Structure of Interfirm Alliances," Journal of Economic Behavior and Organization (38:3), pp. 283-309.

Palmer, J., and Lindemann, M. 2003. "Business Models and Market Mechanisms: Evaluating Efficiencies in Consumer Electronic Markets," ACM SIGMIS Database (34:2), pp. 23-38.

Pfeffer, J., and Salancik, G. R. 1978. The External Control of Organizations: A Resource Dependence Perspective, New York: Harper and Row.

Robey, D., and Sales, C. 1994. Designing Organizations, Burr Ridge, IL: Richard D. Irwin.

Sarker, S., Lau, F., and Sahay, S. 2000. "Building an Inductive Theory of Collaboration in Virtual Teams: An Adapted Grounded Theory Approach," in Proceedings of the $33^{\text {rd }}$ Hawaii International Conference on System Sciences, Los Alamitos, CA: IEEE Computer Society Press.

Schmid, B. 1993. "Electronic Markets," International Journal of Electronic Markets (3:9/10), pp. 3-4.

Strauss, A., and Corbin, J. 1990. Basics of Qualitative Research: Grounded Theory Procedures and Techniques, Newbury Park, CA: Sage Publications.

Tidd, J. 2000. From Knowledge Management to Strategic Competence: Measuring Technological, Market and Organizational Innovation, London: Imperial College Press.

Tidd, J., Bessant, J., and Pavitt, K. 2005. Managing Innovation: Integrating Technological, Market and Organizational Change, Chichester, UK: Wiley \& Sons.

Tilquist, J., King, J., and Woo, C. 2002. "A Representational Scheme for Analyzing Information Technology and Organization Dependency," MIS Quarterly (26:2), pp. 91-118.

Urquhart, C. 1997. "Exploring Analyst-Client Communication: Using Grounded Theory Techniques to Investigate Interaction in Informal Requirements Gathering," in Information Systems and Qualitative Research, A. S. Lee, J. Liebenau, and J. I. DeGross (eds.), London: Chapman and Hall.

Vanhaverbeke, W. 2006. "The Interorganizational Context of Open Innovation," in Open Innovation: Researching a New Paradigm, H. Chesbrough, W. Vanhaverbeke, and J. West (eds.), Oxford, UK: Oxford University Press, pp. 205-219.

Vanhaverbeke, W., and Cloodt, M. 2006. "Open Innovation in Value Networks," in Open Innovation: Researching a New Paradigm, H. Chesbrough, W. Vanhaverbeke, and J. West (eds.), Oxford, UK: Oxford University Press, pp. 258-281.

Weingarten, M. 2007. “'Project Runway' for the T-Shirt Crowd,” Business 2.0 Magazine, June 18(retrieved from http://money.cnn.com/magazines/business2/business2_archive/2007/06/01/ 100050978/index.htm).

West, J., Vanhaverbeke, W., and Chesbrough, H. 2006. "Open Innovation: A Research Agenda," Open Innovation: Researching a New Paradigm, H. Chesbrough, W. Vanhaverbeke, and J. West (eds.), Oxford, UK: Oxford University Press, pp. 285-307 
Williamson, O. E 1981. "The Modern Corporation: Origins, Evolution, Attributes," Journal of Economic Literature (19:4), pp. 1537-1568.

Williamson, O. E. 1991. "Comparative Economic Organization: The Analysis of Discrete Structural Alternatives,” Administrative Science Quarterly (36:2), pp. 269-296.

Williamson, O. E. 1999. "Strategy Research: Governance and Competence Perspectives," Strategic Management Journal (20), pp. 1087-1108.

\section{About the Authors}

Joseph Feller, Ph.D., is a senior lecturer in Business Information Systems at University College Cork, Ireland. His research focuses on open source software and other forms of collaborative production. He has published four books and his work has appeared in leading international journals and conferences including Information Systems Research, Information Systems Journal, Journal of Strategic Information Systems, Journal of Database Management, the International Conference on Information Systems, the European Conference on Information Systems, and working conferences of IFIP. He has also published widely in practitioner-oriented publications and is a frequent contributor to the Cutter Consortium. He was program chair for the IEEE/ACM workshop series on open source software engineering (2001-2005) and the $3^{\text {rd }}$ International Conference on Open Source Systems (IFIP 2.13) and has edited several journal special issues on the subject of open source. He can be reached at jfeller@afis.ucc.ie.

Patrick Finnegan received his Ph.D. from the University of Warwick, England, and is currently a senior lecturer in information systems at University College Cork, Ireland. His research on interorganizational systems and electronic business has been published in a number of international journals and conferences, including Information Systems Research, Information Systems Journal, Information Technology and People, DATABASE, Journal of Information Technology, International Journal of Electronic Commerce, Electronic Markets, the International Conference on Information Systems, the European Conference on Information Systems, and working conferences of IFIP. He is currently an associate editor of Information Systems Journal and president of the Irish Association for Information Systems. He can be reached at p.finnegan@ucc.ie.

Jeremy Hayes is a lecturer in Business Information Systems at University College Cork, Ireland. His research interests are in the area of electronic business models, interorganizational systems, open source software, and business agility. His research is published in leading international journals and conferences, including Information Systems Research, European Journal of Operational Research, Journal of Database Management, the European Conference on Information Systems, and working conferences of IFIP. He can be reached at j.hayes@ucc.ie.

Philip O'Reilly holds a Ph.D. from the National University of Ireland and is a tenured lecturer in Business Information Systems at University College Cork. He is presently involved in research projects focusing on new business forms, open innovation, open source software, and virtual worlds. He has published his research findings at international conferences and journals including the European Conference on Information Systems, the Americas Conference on Information Systems, IIFP Working Group 8.3, Electronic Markets, Journal of Enterprise Information Management, and The Journal of Systems and Information Technology. He can be reached at philip.oreilly@ucc.ie. 